\title{
Drivers, processes and consequences of financial innovation: a research agenda
}

\author{
Anne-Laure Mention* \\ Centre de Recherche Public Henri Tudor, \\ 29 Avenue JF Kennedy, 1855, Luxembourg \\ E-mail: Anne-laure.mention@tudor.lu \\ *Corresponding author

\section{Marko Torkkeli} \\ Lappeenranta University of Technology, \\ Prikaatintie 9, FI-45100 Kouvola, Finland \\ E-mail: Marko.torkkeli@lut.fi
}

\begin{abstract}
It is self-evident that financial innovation is a key player in the contemporary economy. However, its significant importance has largely been overlooked in innovation studies. To fill up this gap, and through an interdisciplinary approach, this article details a research agenda for innovation in financial services. It reviews the 'what', 'why' and 'how' of financial innovation in order to clarify all the ambiguities surrounding its nature, creation, purpose and impact. Specifically, the article investigates its definition and distinguishing features, its key determinants, its supporting processes, and finally its effects, mainly at firm-level. Therefore, the article opens the black box of financial innovation and uncovers its peculiarities in order to understand how it occurs when innovation is considered both as an 'outcome' of financial innovation and a 'process' supporting its creation.
\end{abstract}

Keywords: innovation; financial services; financial innovation; research agenda; literature review; determinants; processes; impact.

Reference to this paper should be made as follows: Mention, A-L. and Torkkeli, M. (2012) 'Drivers, processes and consequences of financial innovation: a research agenda', Int. J. Entrepreneurship and Innovation Management, Vol. 16, Nos. 1/2, pp.5-29.

Biographical notes: Anne-Laure Mention is leading a research unit focusing on innovation economics and management within the Public Research Centre Henri Tudor, Luxembourg. She is actively involved in research projects, mainly focusing on innovation and performance measurement and management in the financial and business to business services industries. Her research interests mainly concentrate on open and collaborative innovation, intellectual capital measurement and management, innovation and technology management. She has been a Visiting Researcher at McGill University, Canada and Ferrara University, Italy. She received an IBM Faculty Award for the project entitled 'Towards accrued transparency of operations in the fund industry' in 2011 focusing on organisational innovation. She is also a founding member of WICI, the Deputy Head of the ISPIM Advisory Board Member and is a member of several scientific committees. 
Marko Torkkeli is a Professor of Technology and Business Innovations at the Lappeenranta University of Technology in Kouvola, Finland. His research interests focus on technology and innovation management, strategic entrepreneurship, growth venturing, and decision support systems. $\mathrm{He}$ has published in journals such as the Int. J. Production Economics, Int. J. Foresight and Innovation Policy, Int. J. Business Excellence, Int. J. Technology Management and Int. J. Technology Intelligence and Planning. He is a member of the editorial boards of the Int. J. of Services Sciences and the Int. J. of Innovation Management. He is a Visiting Researcher at INESC Porto, Portugal, a Docent of Technology-based Business at University of Jyväskylä, Finland and a Docent of Technology and Innovation Management at Helsinki University of Technology, Finland. He serves as the Director of Publications of the International Society for Professional Innovation Management (ISPIM).

\section{Introduction}

Proper functioning of the financial services industry is vital for the well-being of the entire economy. Besides its own importance, the financial sector affects the running of the economy through the products and services it provides to states, other industries and households. Financial services are widely regarded as increasingly innovative. Tether et al. (2001) evidence that financial service firms are more innovative than the average manufacturing firms and show a higher propensity to innovate than service sector firms in general. In their European wide study, Vence and Trigo (2009) also highlight that almost $60 \%$ of financial intermediation firms conduct innovation activities.

The sector itself has been drastically subject to change, resulting from multiple sources: the accrued automation of processes and the increasing role of information and communication technologies; the subsequent waves of regulation, deregulation and re-regulation; the massive trend towards consolidation and constitution of bank-insurance conglomerates, through large mergers and acquisitions; changes in the demand for financial services and in customer preferences; the shift from an intermediation business to fee producing, off balance sheet activities; the introduction of new market players offering competitive products and services, such as loans, credit facilities and insurance contracts; globalisation and increasing cross-border trade (Flier et al., 2001; Goddard et al., 2007; Rossignoli and Arnaboldi, 2009). Digitalisation, dematerialisation and online banking magnify the challenges facing the financial services industry. The introduction of the credit card in the fifties has fuelled the use of electronic money, and a decade later the retail banking industry was further revolutionised with the launch of automated teller machines (ATMs). Nowadays, applications and devices that, when combined with smart phones, enable itinerant businesses and trade persons to accept credit card payments are currently flourishing on the USA and Nordic markets (The Economist, 2012b). Other novelties relying on mobile technologies allow users to top up their phones from selected locations and transfer money to a third-party account. Overall, the sphere of mobile payments is clearly booming, and is, to some extent, simultaneously cooperating and competing with traditional financial services. Incumbent financial firms and their traditional business models also face competition from new market entrants, which sometimes do not belong to the financial sector per se, but nevertheless provide services 
fulfilling similar functions. Peer-to-peer lending solutions providers, whose activities cover transactions between lenders and borrowers, bypass and compete with the traditional banking system, as they occur in parallel to it. The leading online payment company, which now holds a banking license, can be arguably considered as the world's biggest bank with more than 100 million account holders (The Economist, 2012b).

Services such as online financial planning solutions, which gather information from multiple sources and present an aggregated view of one's assets and liabilities, further exemplify financial innovations. The environment in which banking transactions are processed also evolves, with the launch of new types of branches, which offer a wide range of services to customers in completely redesigned atmosphere. Touch-screen televisions, smart phones and tablets replace human cashiers in these concept stores. There, employees do not process operations but focus on customer-centricity. They observe customer behaviour, interact in more natural ways with clients and provide customised advice. Beyond the retail banking sphere, the range of offerings has also drastically widened in the private banking industry, encompassing bundles of services such as tax planning or art advisory.

While most of these innovations undoubtedly contribute to the proper "efficiency and responsiveness of financial markets" (Van Horne, 1985), financial innovation has attracted much controversy in recent times. Nobel Laureate Paul Krugman states that it is "hard to think of any major recent financial innovations that actually aided society" (The New York Times, 2009). Critics of financial innovations argue that recent innovations were not aiming at the "enhancement of the ability of the financial sector to perform its social function" [Joseph Stiglitz, cited by The Economist, (2012a)], but rather embraced "opaque pricing including billing tricks and traps ... that encourages unsafe lending practices" [Pew Charitable Trusts (2009), cited by Lerner and Tufano (2011)], and had hardly any visible effect on the productivity of the economy according to Volcker, quoted in 2009 .

Considering their broad-ranging effects, innovations emanating from financial services arguably deserve scrutiny. Nevertheless, as pointed out by several scholars (e.g., Anderloni and Bongini, 2009; Frame and White, 2004), financial innovations remain largely under-investigated and poorly understood. This observation provides the grounds for this paper, which aims to delineate the various constituents of financial innovation through a holistic review of their discussion in financial innovation literature. More specifically, it tackles the 'what', 'why' and 'how' of financial innovation; that is, it investigates its definition and distinguishing features, its key determinants, its supporting processes, and finally it discusses its effects, mainly at firm-level. Beyond systematically summarising the main pioneering works in the field, the paper aims to further formulate a research agenda in the domain of innovation in financial services. In doing so, it distinguishes itself from the comprehensive review conducted by Frame and White (2004) that surveys empirical contributions, exclusively quantitative, concentrating on the back end of the innovation process, the diffusion of financial innovations, the characteristics of customers and users of innovations as well as the consequences and welfare effects of innovations. Our purpose is to open the black box of financial innovation and explore its peculiarities in order to understand how it happens when innovation is both an outcome of financial innovation and a process for its creation. 


\section{Setting the scene: what is financial innovation?}

Adopting a broad perspective, prominent scholars Lerner and Tufano $(2011$, p.6) recently claimed that financial innovation is "the act of creating and then popularizing new financial instruments, as well as new financial technologies, institutions, and markets", therefore emphasising not only the innovation per se but also its widespread diffusion and adoption.

In Merton's (1992, p.12) words, the "primary function of the financial system is to facilitate the allocation and deployment of economic resources, both spatially and across time, in an uncertain environment". More specifically, the financial system should perform six basic core functions by providing: "ways of clearing and settling payments to facilitate trade; a mechanism for the pooling of resources and for the subdividing of shares in various firms; means to transfer economic resources through time, across borders and among industries; ways to manage risks; price information to help coordinate decentralized decision-making in various economic sectors; ways of dealing with the incentive problems created when one party to a transaction has information that the other party does not or when one party acts as agent for another" [Merton and Bodie, (1995), p.5].

Through this lens of the essential role of the financial system, Frame and White (2004, p.118) define financial innovation as "something new that reduces costs, reduces risks, or provides and improved product/service/instrument that better satisfies participants' demands". According to Frame and White (2004, p.118), financial innovations embrace "new products (e.g. adjustable-rate mortgages, exchange-traded index funds), new services (e.g. Internet banking, online securities trading), new production processes (e.g. credit scoring models, electronic record-keeping for securities), and new organizational forms (e.g. new type of electronic exchange for trading securities, internet-only banks)". Other topical examples of these innovation types encompass social impact bonds, impact investing, e-banking and mobile banking solutions, electronic money processing, branchless banks, alliances with telecommunications providers and mobile network operators, crowdfunding, internal improvement projects, such as Lean and Six Sigma projects for financial services. These types of innovation resonate with the third edition of the OECD (2005, p.46), according to which an innovation is "the implementation of a new or significantly improved product (good or service), or process, a new marketing method, or a new organizational method in business practices, workplace organization or external relations".

In the services literature and more specifically in the demarcation stream (e.g., Djellal and Gallouj, 2001; Gadrey et al., 1995; Sundbo and Gallouj, 2000), scholars have challenged the relevance of distinguishing product and process innovations (e.g., de Jong and Vermeulen, 2003; Toivonen and Tuominen, 2009; Tufano, 2003). Product and process innovations are typically associated with distinct firm strategies. As Cainelli et al. (2006) stress, product innovation is frequently linked to proactive innovation strategies, aiming at introducing radical innovations and thus expecting to generate economic returns. On the other hand, process innovation is often associated with rationalisation, restructuring processes and a more defensive innovation strategy (Cainelli et al., 2006). This classification has been argued to be inapplicable to services, as product and process innovations are intertwined and occur simultaneously. As stated by de Jong and Vermeulen (2003, p.17), "because of the simultaneity of services, product and process innovations usually coincide. New services often go together with new patterns of 
distribution, client interaction, quality control and assurance, etc." Along the same lines, Barras (1990) argue that the introduction of a process innovation often paves the way to improvements in the quality of the service delivered and can even act as an antecedent of product/service innovation. Conversely, Damanpour and Gopalakrishnan (2001) conclude that the product/process dichotomy can be applied to innovation in the banking industry and highlight that process innovation requires different organisational skills than product innovation.

Beyond these traditional definitions and types of innovation, other classifications have emerged, focusing on the functions that innovation allegedly meets (Gadrey et al., 1995; Tufano, 2003), on the economic forces underlying innovations (Llewellyn, 1992) or on their degree of innovativeness (Avlonitis et al., 2001).

Examining the insurance sector, Gadrey et al. (1995) define four types of innovation, according to the function they fulfil. First, innovation in service products primarily targets the development of a new "formula for managing the financial problems of a client or group of clients" (p.7) and often takes the shape of a contract. Second, architectural innovations bundle or unbundle existing service products, so as to provide an integrated service offering or to isolate a subset of service components or operations respectively. The third type refers to innovations that modify the service product through changes to underlying formulas and contracts but give the impression of an unaltered core offering to the client. The final type relates to innovations in processes and organisations, aiming at improving the delivery, extending the distribution channels or implementing new ways of interacting with customers while maintaining the service unchanged in its formal specification.

After critically reviewing existing taxonomies of financial innovation, Tufano (2003) lists six stimuli for financial innovation:

1 innovation exists to complete inherently incomplete markets

2 innovation persists to address inherent agency concerns and information asymmetries

3 innovation enables parties to minimise transaction, search or marketing costs

4 innovation is induced by regulation and taxes

5 innovation is fostered by increasing globalisation, volatility and risk

6 innovation is stimulated by new technologies, including 'intellectual technologies'.

He further concludes that innovation results from several reinforcing and complementary stimulating mechanisms, exemplifying it with major innovations in the investment management sphere.

Llewellyn (1992) identifies four categories of financial innovation, labelled according to the economic forces underpinning their development: defensive, developed in response to changes in regulation and supervision; aggressive, when financial firms elaborate and bring to the market new instruments pursuing a profitability objective; responsive, when the instrument or service is designed to meet customer needs; and protective when financial firms introduce new techniques in order to cope with their own portfolio constraints.

Based on an empirical investigation of 132 new financial services developed and marketed in Greece, Avlonitis et al. (2001) identify six types of financial innovations that represent a "continuum depending on the degree of innovativeness that characterizes each 
type". These innovation types range from 'new to the market' innovations to mere 'service repositionings'. Intermediary types embrace new to the firm innovations, new delivery processes, service modifications and service line extensions. Their development processes are characterised by differentiated cross functionality involvement, activities, level of formality and performance outcomes.

The distinctive features of innovation in financial services have also been emphasised in the literature.

First, the role of regulation either as an innovation catalyst or as a hindrance factor has been widely debated (Marcus, 1981). According to Miller (1986), one of the major drivers of successful innovations over the past two decades was regulation. Conversely, Merton (1995, p.471) argues that regulations can hamper the 'engine of innovation' and constrain the realisation of greater efficiencies in the financial system. Some have claimed that the regulatory dialectic, as coined by Kane (1977), may induce short-term innovations that do not positively affect the financial system in terms of its improved efficiency or market effectiveness in the long term (Anderloni and Bongini, 2009). A concern already raised by Silber (1975), according to whom financial innovation, in the form of financial instruments or practices, may be designed to lessen the financial constraints on firms (Silber, 1983). Lerner (2006) further argues that the regulatory burden may deter young and inexperienced firms due to resource scarcity and, thus, creates a barrier to innovation.

Another peculiarity of financial services pertains to the difficulties faced by the innovators to appropriate and harness the benefits of their novelties. Until recently, most of innovations from financial services were not considered eligible for patent protection (Kumar and Turnbull, 2006; Lerner, 2006). This appropriability concern applies to different extents across continents due to the lack of international harmonisation surrounding the patentability of computerised business methods although financial patents are now commonplace in the USA (Hunt et al., 2009; Tufano, 2003). Lerner (2010) provides evidence that financial patents are being litigated at a much higher rate, by several degrees of magnitude, than that of patents in general. His study unveils that larger entities as well as widely cited patents, usually featuring a high number of claims, are disproportionally prone to litigations. Awareness of the competitive advantages that firms may derive from protecting its critical knowledge assets such as business methods and software solutions, leads financial firms to set up their internal patent department and incentive systems, as exemplified by the Swiss Re case (Bader, 2007). Nevertheless, financial innovations remain easily imitable and their diffusion across competing institutions is fast (Roberts and Amit, 2003). Product innovation has also been evidenced to experience a relatively short lifecycle, as a result of disclosure requirements and lack of formal protection mechanisms (Rossignoli and Arnaboldi, 2009). In contrast, the same authors contend that other forms of innovation, which relate either to organisational structures or operating systems, cannot be easily replicated by competitors and usually mirror significant changes in financial firms.

A third widely debated distinctive pattern of financial services is their propensity to cooperate for innovation activities. Vence and Trigo (2009) find strong evidence of inter-firm cooperation whereas Oliveira and Von Hippel (2011) highlight the importance of users as co-creators in the retail banking industry. Roberts and Amit (2003) also demonstrate that the vast majority of the innovative activity in the retail banking industry relies on ideas sourced from outside the focal firm, thus highlighting the openness nature of the innovation process. In contrast, studies have stressed that customers are rarely 
involved in the innovation process (de Brentani and Cooper, 1992; Vermeulen and Dankbaar, 2002), or they are involved only during the final test and validation stages (Cooper and Edgett, 1996; Thomke, 2003).

At inter-firm level, Lerner (2006) suggests that financial firms cooperate to market new products either through joint ventures or syndications of innovative securities. Besides the product innovation perspective, standards are also of paramount importance in financial services, as they enable the interaction and interoperability between institutions. Recent examples of the prominent role of standards are XBRL, the de facto standard for business information reporting and SEPA, which simplifies and harmonises non-cash transactions. Consoli (2008) reasserts the essential role of inter-firm cooperation, its changing nature and extent and its impact on the development and diffusion of technologically-induced innovations.

Consistently with the service innovation literature (e.g., Tether, 2005), innovation in financial services is usually depicted as incremental. Weak appropriability regimes and ease of imitation combined with resource-intensive, time-consuming and costly innovation process hinder the development of radically new offerings (Alam, 2002; de Brentani, 2001; Easingwood, 1986). Molyneux and Shamroukh (1999) further state that imitators are quicker to develop solutions in the financial sector than in other industries. Consequently, product and service innovation that slightly differ from existing offerings proliferate in the markets. This proliferation and mutation of novelties has been coined as the 'innovation spiral' effect by Merton (1992). According to Merton, as products become standardised and move from intermediaries to markets, the proliferation of trading markets fosters the creation of customised products. These tailored products can then be hedged in new markets, leading to increased volumes, lower transaction costs and incentives to launch more novelties and markets, "spiralling toward the theoretically limiting case of zero marginal transactions costs and dynamically complete markets" (p.468). Me-too products that demonstrate little differentiation from competitive offerings are likely to fail (Alam, 2002) as they lack the necessary uniqueness feature of successful novelties (de Brentani and Cooper, 1992). On the other hand, they are less risky and costly to develop and can as a result be quickly introduced to the market as a response to competition (Avlonitis et al., 2001). Concentrating on modifications to existing products also mitigates the natural risk-aversion attitude of customers (Costanzo and Ashton, 2006).

In this paper, the concept of financial innovation encompasses the process of innovating in financial firms as well as the outcome of this process, i.e., the introduction of novelties to the market, whatever their degree of novelty. Financial innovation therefore embraces changes in the offerings of banks, insurance companies, investment funds and other financial service firms, as well as modifications to internal structures and processes, managerial practices, new ways of interacting with customers and distribution channels.

\section{Determinants of financial innovation}

Factors predicting the occurrence of innovation abound in the literature, with an emphasis on adoption and diffusion patterns of technology-enabled novelties such as ATMs, mobile banking and payments and video banking (e.g., Consoli, 2008; Pennings and 
Harianto, 1992). Size, ownership, market and geographic diversification, competition, organisational structures and past performance are among the most studied factors.

The impact of size, usually measured in terms of assets, on the propensity to innovate remains widely debated in the literature, with conflicting results. Some scholars argue that larger institutions benefit from economies of both scale and scope and are able to access larger pools of resources, including funding sources and to manage their risks more effectively by spreading them over a wider range of lending activities (Gopalakrishnan and Damanpour, 2000; Vives, 2001). On the other hand, larger firms suffer from inertia, are hindered by bureaucratisation and may thus be slower to adapt and less agile (Damanpour, 1992). In their exhaustive survey of empirical literature, Frame and White (2004) identify four studies that evidence a positive effect of banks' size on the likelihood to adopt new technologies so as to widen their offerings and interact with customers. Banks' size is also found to be positively associated to the adoption of electronic payment systems (Buzzacchi et al., 1995), as well as process innovations such as credit scoring (Bofondi and Lotti, 2006). Drawing upon their findings, Buzzacchi et al. (1995) recommend the development of automation consortia and cooperative bodies so as to enable smaller institutions to access an external pool of specialised resources, competencies and equipment. The pattern that larger banks are more innovative also surfaces in Rossignoli and Arnaboldi's (2009) cross country analysis. In his investigation covering a four-year period starting in 2000, Dow (2007) finds a positive relationship between size and likelihood to adopt new technologies, earlier and relying on more advanced versions in the USA credit unions. Similar conclusions are reached by Furst et al. (2002) who unveil that large and profitable institutions enjoying good supervisory ratings, generating large amounts of non-interest income and affiliated with bank holding companies have a higher propensity to operate transactional websites. Positive association between size and likelihood to adopt internet banking as a multichannel strategy has also been evidenced in European studies (Ciciretti et al., 2009; Hernando and Nieto, 2007). In contrast, while exploring financial innovations reported by financial institutions in specialised press and which have been patented in the USA, Lerner (2006) concludes that smaller firms account for a disproportionate share of innovators. Napoli (2008) demonstrates the existence of a negative quadratic relationship between size and innovation in the German banking sector, which supports the claim that large firms may suffer from organisational diseconomies. Likewise, Heffernan et al. (2008) show that the larger the firm, the more likely it is to innovate albeit with diminishing returns in the UK financial services.

Akhavein et al. (2005) confirm the importance of both organisational structures and geographic location on the probability and rate on innovation adoption as more centralised organisations (i.e., having fewer separately chartered banks and more branches) show a higher probability to introduce credit scoring models earlier, as well as organisations headquartered in the New York Federal Reserve district. Likewise, Furst et al. (2002) uncover that being located in urban areas stimulates the adoption of internet enabled innovations. According to Lerner (2006), older and less leveraged firms located in regions where more financial innovations occur also show a higher propensity to innovate. Concentrating on the adoption of transactional websites, DeYoung et al. (2007) evidence that markets with younger and higher educated populations as well as states with more vibrant economies affect the propensity to innovate. Frenz et al. (2005) demonstrate that belonging to a multinational group increases the propensity to engage in 
truly innovative activities, leading to new to the market innovations and to invest more heavily in R\&D activities.

Diversification has mainly been identified as negatively related to innovation likelihood. Contrasting the performance of specialised banks in the USA and Japan with European universal banks, Saunders and Walter (1994) uncover diseconomies of scope in the latter while more focused institutions benefit from economies of super-scale. Vives (2001) also discusses the emergence of diseconomies of management and agency problems in diversified banks. In a similar vein, Boot and Thakor (1997) conclude that financial innovation is stochastically less intense in a universal banking system than in a system where commercial and investment banks remain functionally separated. Furthermore, Bofondi and Lotti (2006) evidence that specialisation positively affects the adoption of credit scoring in the retail banking industry.

Regarding the role of competition, literature also provides conflicting and mixed evidence. Some literature suggests that banks are more likely to innovate as a response to competition and to address institutional challenges rather than to launch novelties which represent ceteris paribus business opportunities (Batiz-Lazo and Wood, 1999, 2003; Batiz-Lazo and Woldesenbet, 2006; Costanzo and Ashton, 2006; Molyneux and Shamroukh, 1996). DeYoung et al. (2007) argue that a more competitive banking sector, characterised by a lower Herfindahl index, fosters the adoption of product and process innovation. In his cross country comparison of innovative payments services, Milne (2006) posits that more concentrated banking systems, such as those found in the Nordic countries, are quicker to adopt such technologies than larger and more fragmented systems. In their exploration of 11 Latin American countries over an eight-year period characterised by large-scale consolidation, restructuring of the market and internationalisation of the sector, Yildirim and Philippatos (2007) conclude that increased competition leads to reduced margins and profitability while boosting cost efficiency. Their findings thereby suggest that process and organisational innovation takes place so as to leverage operational performance. Furthermore, they evidence that foreign ownership and the ratio of foreign institutions to the total banking population are negatively associated with performance measures (ROA and net interest margin), thus improving the efficiency of the overall banking system. These findings resonate with those of several studies covering both developed and emerging economies (Claessens et al., 2001; Claessens and Laeven, 2004; Manlagñit, 2011).

Ciciretti et al. (2009) contend that banks' positive past performance increases the likelihood to introduce technologically-induced innovation. Institutions holding large market shares and operating in concentrated markets are also more likely to be early adopters of process innovations (Bofondi and Lotti, 2006). Lerner (2006) argues that less profitable firms are more likely to innovate than their peers while reaping the fruits of their investment in subsequent years in the forms of enhanced profitability. Similarly, Akhavein et al. (2005) claim that less profitable organisations are more likely to adopt credit scoring techniques for small business loan applications earlier.

Consistently with most of prior innovation literature examining the role of $R \& D$ investment, past R\&D expenditures and continuous commitment to innovation activities have been evidenced to positively affect innovation propensity (Napoli, 2008) and performance (Heffernan et al., 2008).

Postulating that product and process innovations are related to different objectives and should be explored separately yet simultaneously, Batiz-Lazo and Woldesenbet (2006) argue that larger banks are more inclined into process innovation than product 
innovation, as they aim to increase efficiency of operations instead of venturing into new products and markets. Their study provides no clear cut evidence on whether product innovation precedes process innovation or whether both innovation types occur simultaneously. Likewise, Damanpour and Gopalakrishnan (2001) study product and process innovations separately. The scholars further delineate innovation into its rate and speed of adoption, which refers to the readiness of an organisation to draw from an available pool of innovations and the time elapsed between the innovation is firstly introduced and adopted by the focal firm, respectively. Their investigation highlights that US commercial banks adopt product innovations at a greater rate and speed than process innovations, suggesting that executives presumably target first mover advantage. In another study of US commercial banks, Gopalakrishnan and Damanpour (2000) examined the effects of size, geographic scope and product scope on product and process innovation types, disentangling the effects on innovation magnitude, defined as the innovation extensiveness and innovation speed, which refers to the quickness to adopt innovation. They find evidence of a higher impact of geographic scope and size on innovation magnitude than on innovation speed, and a stronger association between geographic scope and product innovation than with process innovation. Their study also reveals that narrowing product scope is positively related to innovation speed rather than magnitude. Further delineating the different product scopes into individual, real estate and commercial products, they unveil that individual product scope is more strongly related to the speed of product innovation than process innovation whereas the opposite is observed for commercial product focus. Another innovation driver is the willingness to retain tacit knowledge within the organisation (Batiz-Lazo and Woldesenbet, 2006).

\section{How financial innovation happens}

This section aims to further open the black box of financial innovation and examines the ingredients and processes of innovation in financial service firms. Literature concentrating on how financial service firms organise their innovation activities remains scarce (Costanzo et al., 2003) despite the fact that it slightly differs from innovation in manufacturing settings. Differentiating elements include, amongst others, the absence of a specific organisation unit responsible for R\&D activities and the lack of dedicated R\&D budgets (Arderloni and Bongini, 2009; Frame and White, 2004). Yet, as Rossignoli and Arnaboldi (2009) stress, the existence of a research and development function mobilising different organisational units cannot be ruled out.

Anderloni and Bongini (2009, p.45) conclude that "there is a systematic informational deficit, arising from rigorous empirical studies, as to how banks organize their R\&D activities to promote innovation and which of these organizational choices successfully sponsor financial innovation". A vast majority of the studies focusing on the innovation process in financial services can be traced back to the new product and service development stream (e.g., de Brentani, 1989, 1991, 1993; de Brentani and Cooper, 1992; Edgett and Jones, 1991; Storey and Easingwood, 1993, 1996) and to the organisational behaviour literature (e.g., Thwaites, 1992; Thwaites and Edgett, 1991; Vermeulen, 2004 Vermeulen and Dankbaar, 2002).

Adopting a systematic approach to service innovation through effective and formal new service development process, which may be equally important to that in manufacturing, may yield higher returns and is now commonplace in financial service 
firms (de Brentani, 2001; Edgett and Jones, 1991; Froehle et al., 2000; Johne and Harborne, 2003; Johne and Storey, 1998; Kelly and Storey, 2000; Reidenbach and Moak, 1986).

Contrasting 106 successful and unsuccessful new financial services, de Brentani and Cooper (1992) reveal five main determinants of success. The extent to which the novelty meets the customer's needs is of primary importance in predicting innovation success. The quality of marketing activities as well as the internal efforts prior to the launch of the new service play a dominant role in success. Another key factor is the existence of synergies between the existing offerings and the novelty, as it enables firms to fully exploit their expertise and strengths. Skills of the personnel in charge of provisioning the service are also critical, and finally the positioning of the new service, its differentiating factors and uniqueness features also show paramount importance in determining the success of the novelties. Storey and Easingwood (1996) extend this list by adding two factors of strategic importance in determining success in financial services: distribution strength and effective communication. The former refers to the extensive access to the target market and the existence of synergy in distribution channels between new offerings and incumbent products whereas the latter encompasses the advertising and promotion effectiveness, the creating awareness capability and the ability to build a strong image.

Several studies have adopted a similar research design, contrasting success and failure innovation cases and relying on executives' perceptions (e.g., Carvalho Viera et al., 2004; Edgett and Parkinson, 1994; Lievens and Moenaert, 2000; Oldenboom and Abratt, 2000). Carvalho Viera et al. (2004) highlight the influence of strategic factors such as global quality, marketing effort, degree of innovativeness to the market and existence of a NSD process on the overall success of new financial services but fail to uncover the effects of environmental factors such as market competitiveness and regulation. Further delineating success into several financial and intangible measures, marketing efforts and innovativeness to the market are confirmed as key determinants of new financial services success. Taking into consideration the degree of novelty of the innovation, Papastathopoulou et al. (2006) conduct an in-depth investigation of which functions are involved at the different stages of the NSD process and how it affects the performance of its outcome. Their study concludes that the involvement of the marketing function is a key success factor throughout the entire process of new to the market innovation development and echoes the findings of Scheuing and Johnson (1989) who stress that the marketing function is largely in charge of the new product development process. They further emphasise the importance of involving frontline personnel as well as operations staff throughout the process due to their essential role in service quality and their knowledge of customers. In the same vein, Johne and Davies (2000) stress that achieving realistic appraisal of market opportunities, realising the potentials of distinct market segments and designing new ways of approaching the markets are essential success factors. In contrast, operations and IT functions hold a dominant role in the development of imitative products, where emphasis should be on improving the delivery process and addressing the failures of competitive offerings (Papastathopoulou et al., 2006). Lievens and Moenaert (2000) examined the impact of communication on the innovation process and on its success, integrating the peculiarities of services as mediating variables. Their investigation uncovers the crucial effect of intra-project communication on resource, technological and customer uncertainty reduction as well as the essential role of so-called information gatekeepers (i.e., front office personnel) and organisational liaisons as predictors of the uncertainty reduction about customers and competitors, respectively. 
Furthermore, reducing customer and resource uncertainty has been evidenced to significantly contribute to both perceived financial and technological success.

Investigating the innovation process in financial services in North American institutions, Drew (1995) identifies organisational barriers and enablers to fast new product and service innovation. Barriers to fast innovation process include lack of focused strategy, insufficient support from senior management, organisational inflexibility and employee turnover. An external factor, which is poor economic conditions, also affects the rapidity of the new product and service development process. His study highlights the importance of market orientation, relying both on customer and employee insights, the adoption of a proactive attitude to product development, the essential role of designing strategic plans and setting goals for innovations, the positive effect of having separate unit for R\&D and innovation and the crucial role of skills and diversity rewarding schemes as enablers of a speedy innovation process.

Further exploring the peculiarities and the barriers facing banks and insurance firms in their innovation process, Vermeulen (2004) reveals that the innovation process is, to some extent, formalised around the following phases: idea generation, concept development, building and implementation. His longitudinal multiple case study research unveils that innovation is usually conducted by multidisciplinary teams, consisting of members that remain first and foremost representatives of their functional departments and who dedicate only part of their time to the new product development project. These teams are set up on an ad hoc basis, after positively going through the screening stage, and rarely involve front office personnel and intermediaries. According to Vermeulen (2004), customers are rarely involved in the innovation process and products often end up on the market without prior analysis of customers' interests for these novelties. This finding echoes the conclusion of de Brentani and Cooper (1992, p.235), according to whom "most new service products are not market tested". It also resonates with the conclusions of Costanzo and Ashton (2006) who argue that the innovation process is more market-oriented than customer-oriented, thus targeting the quick introduction of slightly modified offerings as a response to competition rather than truly identifying and meeting customers' needs. The lack of systematic efforts to collect ideas and to source information from the front office personnel is also evidenced by Vermeulen and Dankbaar (2002). The scholars further state that "direct involvement of customers appears extremely rare" and may be explained by the degree of inherent complexity of financial innovation and the lack of customer interest in these innovations [Vermeulen, (2004), p.94]. Whereas involving customers in the co-creation process may be rewarding, it is complex as customers may not be able to clearly articulate their needs (Avlonitis et al., 2001) and further requires a careful selection of the participants showing a sufficient level of motivation (Auh et al., 2007). Athanassopoulou and Johne (2004) emphasise the benefits of involving continuously carefully selected customers in the new service development process. Nevertheless, Menor and Roth (2008) conclude that market acuity, defined as the ability to simultaneously comprehend the competitive landscape and to anticipate and meet customers' evolving needs, is the most important new service development competence, which in turn affects new service development performance. Listening to customers' feedback and more specifically sources of dissatisfaction has however been evidenced to positively affect innovativeness, conditional upon the quality of the relationship with the investment consultant (Yang et al., 2009). Vermeulen (2004) identifies four major barriers to product innovation in the financial industry: functionally departmentalised structures, which inevitably lead to resource conflicts and prioritisation 
of daily activities, with subsequent product development delays; limited use of new product development tools, including project management as organisational mode and lack of communication among team members; conservative organisational culture and risk aversion and constraints from legacy IT systems, preventing adaptability and interoperability. According to Vermeulen and Dankbaar (2002), if innovation usually originates from multidisciplinary work groups, most of the work is actually conducted in mono-disciplinary teams, leading to vertical communication flows rather than horizontal ones. Still at intra-organisational level, Vermeulen et al. (2007) explore the impact of micro institutional forces on the process leading to incremental product innovations in banks and insurance companies. Their study indicates that the micro regulatory, normative and cultural-cognitive forces are clearly interwoven and reinforce themselves to shape two distinct organisational templates, one 'business as usual' and one 'innovation'. Contrasting successful and unsuccessful innovation projects, they argue that the successful projects were dominated by an 'innovation template'. This approach suggests departing from applicable standard rules and policies, isolating innovative projects and accepting the inherent risks of the innovation journey. This conclusion contradicts prior literature which suggests applying corporate rules to all projects, including innovation ones, as it contributes to sustain their legitimacy (e.g., Aldrich and Fiol, 1994).

Another relatively recent strand of studies has explored the applicability of total quality management methods such as Lean, Six Sigma, combined Lean-Six Sigma, theory of constraints in financial services (Azis and Osada, 2011; Kumar et al., 2008; Lin, 2008). Others have investigated business process reengineering methods and their effects on the introduction of novelties and on performance improvement (e.g., Akamavi et al., 2001; Maull and Childe, 1994; Shin and Jemella, 2002), or focused on improvement to financial services and operational efficiency using process mapping techniques and flowchart (Akamavi, 2005). Studies have concluded that these approaches support process innovation and facilitate incremental innovation (De Koning et al., 2008), enable to quickly identify the weaknesses in service and transactional processes and focus on areas where improvement yields higher returns in terms of true savings and revenue growth (Uprety, 2009).

\section{Effects of financial innovation}

Innovation in financial services may affect the operations and the performance of financial firms themselves and may also impact society as a whole through the rapid diffusion and wide adoption mechanisms of their novelties. The intended and unintended effects of financial innovation on society have attracted much interest recently. Lerner and Tufano (2011) argue that assessing the social consequences of financial innovation is a challenging task and adopt a counterfactual approach to examine the social welfare implications of three particular innovations. Sveiby (2012) discusses the pro-innovation bias and states that innovation may have unintended and negative consequences affecting society as a whole. Den Haan and Sterk (2010, p.707) contend that financial innovation plays a role in moderating business cycles, by reducing frictions in lending and thus allowing financial intermediaries to "continue to fulfill their role efficiently during an economic downturn". Lerner and Tufano (2011, p.45) underline the interconnectedness 
of the financial system, with the inevitable consequence that financial innovation will "generate a complex web of externalities, both positive and negative".

Goddard et al. (2007, p.1926) state that major changes to internal systems in the banking industry, such as "customer relationship management systems, business management technologies, core processing technologies and various support and integration technologies" have positively impacted performance and profitability. At macroeconomic level, some studies have explored the effect of technological change on the productivity growth and efficiency gains, either in European settings (Altunbas et al., 1999; Casu et al., 2004) or emerging economies (Howcroft and Ataullah, 2006). At firm-level, few studies have investigated the effects of financial innovation on the performance on financial institutions, using either objective performance measures or relying on perceptions. This paucity of empirical research in this field is a consequence of the absence of relevant datasets and the observation that financial innovation fits neither with the R\&D nor the patent count tradition, as Frame and White (2004) argue.

Along these lines, Haskel and Pesole (2011) allude that banks have the lowest R\&D intensity in the official UK R\&D scoreboard, a figure computed using national account data, which allows only software in the course of development to be counted as R\&D. They consequently advocate adopting a wider perspective on R\&D to investigate the relationship between innovation and productivity in financial services. This approach encompasses investment in three main categories of intangible assets: computerised information (software and databases), innovative property (mainly product development and design) and economic competencies (such as branding, firm-funded training, firm-specific human capital and organisational investment). Investment in those intangibles is evidenced to be a vital component of financial innovation and is understated in the traditional accounting framework. Integrating them into growth accounting leverages the understanding of total factor productivity growth. Their analysis extends works conducted at macroeconomic level to identify the contribution of intangibles to economic growth, which have evidenced that they have a large impact on both growth and labour productivity. Incorporating such intangibles improves the understanding of growth and provides explanation for part of the residual multifactor productivity (Corrado et al., 2005, 2006, 2009; Van Ark et al., 2009).

As aggregate consists of smaller units, we further concentrate on firm-level studies that assess the impact of innovation on performance, relying either on objective and factual measures (e.g., Ciciretti et al., 2009; Hernando and Nieto, 2007; Roberts and Amit, 2003; Rossignoli and Arnaboldi, 2009) or perceptual measures (Avlonitis et al., 2001; Batiz-Lazo and Woldesenbet, 2006; Damanpour and Gopalakrishnan, 2001), collected among key informants (Phillips, 1981).

In an investigation of 58 financial innovations spanning from 1974 to 1986, Tufano (1989) finds evidence that innovators from the investment banking industry capture higher market shares than followers with their introduction of new products, despite the rapid release of imitative products. His study further uncovers that the development costs (covering legal, accounting, regulatory fees; training of issuers, investors and traders; dedicated pricing and trading information systems; human resources and capital for market making activities and remuneration of groups that developed the new financial products) for imitators can be halved compared to first movers.

In their analysis of the effect of new products and processes on financial performance, measured by ROA, in the Australian retail banking industry, Roberts and Amit (2003) conclude that banks which pursue actively and consistently innovation activities over 
time and whose portfolio of innovation activities was slightly differentiated from the industry enjoyed superior financial performance. Interestingly, their study finds no evidence of first mover advantage and confirms that products only new to the firm may lead to competitive positions. This echoes the findings of Lopez and Roberts (2002) who evidence that pioneer's competitive advantage, measured by the evolution of its market share, may erode quickly if subsequent entrants invade the market rapidly after the introduction of the innovation. Conversely, Abir and Chokri (2010) conclude that being a first mover product innovator bestows banks with improved profitability while first mover process innovators enjoy superior profitability and efficiency in the emerging Tunisian banking industry. Investigating the relationship between innovation and both the dynamics of profitability measured as the percent variation of the ROA and the incidence of operating costs, measured as the percent variation of the cost-income ratio, Rossignoli and Arnaboldi (2009) show that the most innovative UK banks experience a more significant decline of their cost-income ratio but could not evidence significant relationship between innovation and profitability.

Several studies have concentrated on the impact of technology-enabled innovations such as ATMs and internet banking systems, which combine characteristics of both product and process types, on performance. Relying on 38 performance measures from income statements and balance sheets, DeYoung et al. (2007) contrast early adopters of transactional websites with their 'brick-and-mortar' counterparts. Their study evidences that this additional delivery channel leads to non-trivial increases in bank profitability, primarily resulting from the willingness of customers to pay for extra fee-based services. They also conclude that transactional websites complement rather than substitute other delivery channels. Likewise, Hernando and Nieto (2007) contend that internet banking is a complementary strategy to reach customers. Their study of Spanish commercial banks uncovers that the adoption of internet banking practices as an additional delivery channel has significant positive effects on banks profitability, measured in terms of ROA and on ROE, after a period of 18 months and three years has elapsed respectively. Analysing the Italian banking industry, Ciciretti et al. (2009) find evidence of strong association between the adoption of transactional websites to offer new services and profitability measures. Yet, they unveil a marginally significant correlation between risk measures and internet banking activities, which may be attributable to the diversification of assets and broader geographical reach. Their findings suggest that further research on the effects of such practices on risk is needed.

In their qualitative exploration of the commercial banking industry in the UK, Batiz-Lazo and Woldesenbet (2006) conclude that being first mover to the market is not perceived as a key innovation driver by senior managers and management consultants and report contrasted views on whether being a first mover confers a competitive advantage. Their study further delineates the effects of product and process innovations on performance, contending that they both contribute in their own way to performance, either in the form of increased revenues or of improved efficiency and cost reduction, respectively. How financial innovation impacts performance should also be explored considering the market focus and the degree of automation of activities, thus contrasting retail with investment and corporate banking according to these authors.

Investigating the impact of new service on performance, Avlonitis et al. (2001) conclude that the degree of novelty has strong influence on the financial performance, measured in terms of profitability and market share development. Their study unveils an inverted U-shaped relationship between financial performance and the degree of 
innovativeness of new services, thus concluding that new delivery processes and service modifications are contributing most to profitability and market share growth.

Relying on a mix of factual and perceptual measures of performance, Damanpour and Gopalakrishnan (2001) investigate whether product innovation precedes process innovation in high performing commercial banks. Their findings provide partial support for this sequence but a further analysis suggests that high performance banks tend to introduce synchronously process and product innovations. Joint strategies of product and process innovations allow benefiting simultaneously from efficiency improvement and a wider range of offerings to address market and customer needs.

\section{Financial innovation: a research agenda}

This paper aimed at shedding light on the existing body of knowledge focusing on financial innovation, characterising it, underlying its determinants, exploring how financial innovation occurs and assessing its effects, mainly at firm-level. In order to do so, it reviewed several literature strands, such as innovation economics and management, organisational behaviour and banking studies, as Table 1 illustrates. This review unveiled that literature on financial innovation is largely fragmented and confirms that both the phenomenon and its outcomes remain poorly understood. In doing so, it also uncovers several avenues for further research.

Table 1 Selected studies on financial innovation

\begin{tabular}{|c|c|c|}
\hline Scope & Main focus & Selected references \\
\hline \multirow[t]{4}{*}{$\begin{array}{l}\text { Defining } \\
\text { innovation }\end{array}$} & Typologies and taxonomies & $\begin{array}{l}\text { Avlonitis et al. (2001), Gadrey et al. (1995), } \\
\text { Frame and White (2004), Llewellyn (1992), } \\
\text { Lerner and Tufano (2011), Merton (1992), } \\
\text { Merton and Bodie (1995), and Tufano (2003) }\end{array}$ \\
\hline & Role of regulation & $\begin{array}{c}\text { Anderloni and Bongini (2009), Lerner (2006), } \\
\text { Marcus (1981), Merton (1995), Miller (1986), } \\
\text { and Silber }(1975,1983)\end{array}$ \\
\hline & Intellectual property & $\begin{array}{l}\text { Bader (2007), Hunt et al. (2009), Kumar and } \\
\text { Turnbull (2006), Lerner (2006, 2010), Roberts } \\
\text { and Amit (2003), and Tufano (2003) }\end{array}$ \\
\hline & $\begin{array}{l}\text { Openness, as a typical feature } \\
\text { of innovation in services }\end{array}$ & $\begin{array}{c}\text { Consoli (2008), Lerner (2006), and Vence and } \\
\text { Trigo (2009) }\end{array}$ \\
\hline \multirow[t]{3}{*}{$\begin{array}{l}\text { Innovation } \\
\text { determinants }\end{array}$} & Size & $\begin{array}{l}\text { Buzzacchi et al. (1995), Ciciretti et al. (2009), } \\
\text { Damanpour and Gopalakrishnan (2001), Dow } \\
\text { (2007), Furst et al. (2002), Hernando and } \\
\text { Nieto (2007), Lerner (2006), Napoli (2008), } \\
\text { and Rossignoli and Arnaboldi (2009) }\end{array}$ \\
\hline & Diversification & $\begin{array}{c}\text { Bofondi and Lotti (2006), Boot and Thakor } \\
\text { (1997), Gopalakrishnan and Damanpour } \\
\text { (2000), Saunders and Walter (1994), and } \\
\text { Vives (2001) }\end{array}$ \\
\hline & Competition & $\begin{array}{l}\text { Batiz-Lazo and Wood (1999, 2003), Batiz- } \\
\text { Lazo and Woldesenbet (2006), Costanzo and } \\
\text { Ashton (2006), Milne (2006), and Molyneux } \\
\text { and Shamroukh (1996) }\end{array}$ \\
\hline
\end{tabular}


Table 1 Selected studies on financial innovation (continued)

\begin{tabular}{|c|c|c|}
\hline Scope & Main focus & Selected references \\
\hline \multirow[t]{3}{*}{$\begin{array}{l}\text { Innovation } \\
\text { determinants }\end{array}$} & Organisational structures & $\begin{array}{l}\text { Akhavein et al. (2005), DeYoung et al. } \\
\text { (2007), Frenz et al. (2005), and Lerner (2006) }\end{array}$ \\
\hline & Geographic locations & Akhavein et al. (2005) and Furst et al. (2002) \\
\hline & Past performance & $\begin{array}{l}\text { Akhavein et al. (2005), Bofondi and Lotti } \\
\text { (2006), Ciciretti et al. (2009), Heffernan et al. } \\
\text { (2008), and Lerner (2006) }\end{array}$ \\
\hline \multirow[t]{7}{*}{$\begin{array}{l}\text { Innovation } \\
\text { process }\end{array}$} & Communication & $\begin{array}{l}\text { Lievens et al. (1999) and Lievens and } \\
\text { Moenaert }(2000,2001)\end{array}$ \\
\hline & Role of marketing function & $\begin{array}{c}\text { de Brentani and Cooper (1992), Costanzo and } \\
\text { Ashton (2006), Johne and Davies (2000), } \\
\text { Menor and Roth (2008), Papastathopoulou } \\
\text { et al. (2006), and Scheuing and Johnson } \\
\text { (1989) }\end{array}$ \\
\hline & $\begin{array}{l}\text { Importance of NPD/NSD } \\
\text { process }\end{array}$ & $\begin{array}{l}\text { de Brentani (2001), Carvalho Veira et al. } \\
\text { (2004), Edgett and Jones (1991), and Johne } \\
\text { and Harborne (2003) }\end{array}$ \\
\hline & Customer involvement & $\begin{array}{l}\text { Avlonitis et al. (2001), Auh at al. (2007), } \\
\text { Athanassopoulou and Johne (2004), Johne and } \\
\text { Harborne (1985), Oliveira and Von Hippel } \\
\text { (2011), and Yang et al. (2009) }\end{array}$ \\
\hline & $\begin{array}{l}\text { Process improvement and } \\
\text { business reengineering } \\
\text { approaches }\end{array}$ & $\begin{array}{c}\text { Akamavi (2005), Akamavi et al. (2001), Azis } \\
\text { and Osada (2011), Kumar et al. (2008), and } \\
\text { De Koning et al. (2008) }\end{array}$ \\
\hline & $\begin{array}{l}\text { Multidisciplinarity, cross } \\
\text { functional teams }\end{array}$ & Vermeulen and Dankbaar (2002) \\
\hline & Barriers to innovation & $\begin{array}{c}\text { Drew (1995), Vermeulen (2004), and } \\
\text { Vermeulen et al. (2007) }\end{array}$ \\
\hline \multirow[t]{4}{*}{$\begin{array}{l}\text { Effects of } \\
\text { innovation }\end{array}$} & $\begin{array}{l}\text { Financial effects and } \\
\text { productivity impact }\end{array}$ & $\begin{array}{c}\text { Altunbas et al. (1999), Casu et al. (2004), } \\
\text { Goddard et al. (2007), and Howcroft and } \\
\text { Ataullah (2006) }\end{array}$ \\
\hline & $\begin{array}{l}\text { At firm-level: financial and } \\
\text { intangible effects }\end{array}$ & $\begin{array}{l}\text { Abir and Chokri (2010), Avlonitis et al. } \\
\text { (2001), Batiz-Lazo and Woldesenbet (2006), } \\
\text { Damanpour and Gopalakrishnan (2001), } \\
\text { DeYoung et al. (2007), Hernando and Nieto } \\
\text { (2007), Ciciretti et al. (2009), and Rossignoli } \\
\text { and Arnaboldi (2009) }\end{array}$ \\
\hline & Sectoral analysis & Haskel and Pesole (2011) \\
\hline & Societal & $\begin{array}{l}\text { Den Haan and Sterk (2010), Lerner and } \\
\text { Tufano (2011), and Sveiby (2012) }\end{array}$ \\
\hline
\end{tabular}

First, despite the existence of several typologies and taxonomies, which mainly emanate from the innovation economics literature, characterising and uncovering features of financial innovation could be an interesting area of research. Convergence between technologies and industries, such as mobile technologies, payment platforms and transactional services deserves further scrutiny, as well as how these industry trends affect the speed and magnitude of innovation. 
Second, evidence on the determinants of financial innovation remains relatively mixed and ambiguous. Additionally, most of the research has hitherto focused on the determinants of product or process innovations, disregarding the other forms of innovation. While some research has focused on the diffusion of technology-enabled innovations (e.g., Consoli, 2008), as well as the acceptance by consumers of these novelties (e.g., Lin, 2011), few studies have explored the underlying rationales for most of innovation types.

Third, exploring how financial innovation occurs certainly represents a fruitful and rewarding area for further research. An R\&D focus, inherited from the industrialist approach to innovation, is inappropriate to the context of financial innovation (Frame and White, 2004; Haskel and Pesole, 2011). Nevertheless, innovation activities are scattered across teams, dispersed in organisations. Intra- and inter-firm communication, multidisciplinarity, cross functionality have been uncovered as key success factors in the new product development and organisational behaviour literature streams (e.g., Lievens and Moenaert, 2000; Storey and Easingwood, 1996; Vermeulen, 2004). Nevertheless, much remains to be understood about related optimum levels, structural designs and interaction among teams and how innovation activities are articulated and coordinated. Little is known about the involvement of customers (e.g., Oliveira and Von Hippel, 2011), how to adequately select and integrate them into the innovation process, and what incentives should be implemented in order to elicit, capture and anticipate their needs. Beyond customers, the degree of openness of the innovation process through embracing collaboration with other stakeholders, such as service providers, professional associations and regulatory bodies has hardly been touched upon. Empirical studies focusing on intraand inter-firm cooperation practices aiming at exploring their effects on the innovation process and on its outcome should be particularly relevant.

Finally, the effects of financial innovation on performance at firm-level, adopting a multifaceted approach to performance so as to encompass financial and business performance but also organisational effectiveness (Venkatraman and Ramanujam, 1986) should be further examined. While a positive effect of innovation on performance is usually observed, it is rarely backed by factual data. Additionally, studies concentrating on the optimal combination of me-too products and services versus radical novelties so as to ensure short term results and long term competitiveness may lead to insightful implications for innovation managers. Studying outperforming firms could also rewarding, as well as analysing innovation portfolios of firms that sustained their performance and competitiveness levels during the economic downturn. Further understanding financial innovation, delineating it into its constitutive intangible elements along the lines of Haskel and Pesole's (2011) study, and exploring its impact on productivity and growth should provide relevant insights for policy makers and business leaders alike.

\section{References}

Abir, M. and Chokri, M. (2010) 'Dynamic of financial innovation and performance of banking firms: context of an emerging banking industry', International Research Journal of Finance and Economics, No. 51, pp.17-37.

Akamavi, R.K. (2005) 'Re-engineering service quality process mapping: e-banking processes', International Journal of Bank Marketing, Vol. 23, No. 1, pp.28-53. 
Akamavi, R.K., Charrington, S., Gledhill, C. and Cowie, S. (2001) 'Process mapping re-engineering the opening student account: the case of Lloyds TSB Bank', Journal of Financial Services Marketing, Vol. 5, No. 3, pp.246-262.

Akhavein, J., Frame, W.S. and White, L.J. (2005) 'The diffusion of financial innovations: an examination of the adoption of small business credit scoring by large banking organizations', The Journal of Business, Vol. 78, No. 2, pp.577-596, University of Chicago Press.

Alam, I. (2002) 'An exploratory investigation of user involvement in new service development', Journal of the Academy of Marketing Science, Vol. 30, No. 3, pp.250-261.

Aldrich, H. and Fiol, C.M. (1994) 'Fools rush in? The institutional context of industry creation', Academy of Management Review, Vol. 19, No. 4, pp.645-670.

Altunbas, Y., Goddard, J. and Molyneux, P. (1999) 'Technical change in banking', Economics Letters, Vol. 64, No. 2, pp.215-221.

Anderloni, L. and Bongini, P. (2009) 'Is financial innovation still a relevant issue?', in Anderloni, L., Llewellyn, D.T. and Schmidt, R.H. (Eds.): Financial Innovation in Retail and Corporate Banking, pp.41-62, Edward Elgar, Cheltenham.

Athanassopoulou, P. and Johne, A. (2004) 'Effective communication with lead customers in developing new banking products', International Journal of Bank Marketing, Vol. 22, No. 2, pp.100-125.

Auh, S., Bell, S.J., McLeod, C.S. and Shih E. (2007) 'Co-production and customer loyalty in financial services', Journal of Retailing, Vol. 83, No. 3, pp.359-370.

Avlonitis, G.J., Papastathopoulou, P.G. and Gounaris, S.P. (2001) 'An empirically based typology of product innovativeness for new financial services: success and failure scenarios', Journal of Product Innovation Management, Vol. 18, No. 5, pp.324-342.

Azis, Y. and Osada, H. (2011) 'An empirical study of new value creation in financial service companies using design for Six Sigma approach', International Journal of Productivity and Quality Management, Vol. 7, No. 1, pp.104-124.

Bader, M.A. (2007) 'Managing intellectual property in the financial services industry sector: learning from Swiss Re', Technovation, Vol. 28, No. 4, pp.196-207.

Barras, R. (1990) 'Interactive innovation in financial and business services: the vanguard of the service revolution', Research Policy, Vol. 19, No. 3, pp.215-237.

Batiz-Lazo, B. and Woldesenbet, K. (2006) 'The dynamics of product and process innovation in UK banking', International Journal of Financial Services Management, Vol. 1, No. 4, pp.400-421.

Batiz-Lazo, B. and Wood, D. (1999) 'Management of core capabilities in Mexican and European banks', International Journal of Service Industry Management, Vol. 10, No. 5, pp.430-448.

Batiz-Lazo, B. and Wood, D. (2003) 'Strategy, competition and diversification in European and Mexican banking', Electronic Markets, Vol. 12, No. 3, pp.192-205.

Bofondi, M. and Lotti, F. (2006) 'Innovation in the retail banking industry: the diffusion of credit scoring', Review of Industrial Organization, Vol. 28, No. 4, pp.343-358.

Boot, A.W.A. and Thakor, A.V. (1997) 'Banking scope and financial innovation', The Review of Financial Studies, Vol. 10, No. 4, pp.1099-1131.

Buzzacchi, L., Colombo, M.G. and Mariotti, S. (1995) 'Technological regimes and innovation in services: the case of the Italian banking industry', Research Policy, Vol. 24, No. 1, pp.151-168.

Cainelli, G., Evangelista, R. and Savona, M. (2006) 'Innovation and economic performance in services: a firm-level analysis', Cambridge Journal of Economics, Vol. 30, No. 3, pp.435-458.

Carvalho Veira, J.M., de Magalhaes Serra, E. and Gonzalez, J.A.V. (2004) 'New services margin/high success discriminators', The Service Industries Journal, Vol. 24, No. 5, pp.91-101. 
Casu, B., Girardone, C. and Molyneux, P. (2004) 'Productivity change in European banking: a comparison of parametric and non-parametric approaches', Journal of Banking \& Finance, Vol. 28, No. 10, pp.2521-2540.

Ciciretti, R., Hasan, I. and Zazzara, C. (2009) 'Do internet activities add value? Evidence from the traditional banks', Journal of Financial Services Research, Vol. 35, No. 1, pp.81-98.

Claessens, S. and Laeven, L. (2004) 'What drives bank competition? Some international evidence', Journal of Money, Credit, and Banking, Vol. 36, No. 3, pp.563-584.

Claessens, S., Demirguc-Kunt, A. and Huizinga, H. (2001) 'How does foreign entry affect domestic banking markets?', Journal of Banking and Finance, Vol. 25, No. 5, pp.891-911.

Consoli, D. (2008) 'Systems of innovation and industry evolution: the case of retail banking in the UK', Industry and Innovation, Vol. 15, No. 6, pp.579-600.

Cooper, R.G. and Edgett, S.J. (1996) 'Critical success factors for new financial services', Marketing Management, Vol. 5, No. 3, pp.26-38.

Corrado, C., Hulten, C. and Sichel, D. (2005) 'Measuring capital and technology: an expanded framework', in Corrado, C. et al. (Eds.): Measuring Capital in the New Economy, pp.11-45, The University of Chicago Press, Chicago and London.

Corrado, C., Hulten, C. and Sichel, D. (2006) 'Intangible capital and economic growth', NBER Working paper No. 11948.

Corrado, C., Hulten, C. and Sichel, D. (2009) 'Intangible capital and US economic growth', Review of Income and Wealth, Vol. 55, No. 3, pp.661-685.

Costanzo, L.A. and Ashton, J.K. (2006) 'Product innovation and consumer choice in the UK financial services industry', Journal of Financial Regulation and Compliance, Vol. 14, No. 3, pp.285-303.

Costanzo, L.A., Keasey, K. and Short, H. (2003) 'A strategic approach to the study of innovation in the financial services industry: the case of telephone banking', Journal of Marketing Management, Vol. 19, Nos. 3-4, pp.259-281.

Damanpour, F. (1992) 'Organizational size and innovation', Organization Studies, Vol. 13, No. 3, pp.375-402.

Damanpour, F. and Gopalakrishnan, S. (2001) 'The dynamics of the adoption of product and process innovations in organizations', Journal of Management Studies, Vol. 38, No. 1, pp.45-65.

de Brentani, U. (1989) 'Success and failure in new industrial services', Journal of Product Innovation Management, Vol. 6, No. 4, pp.239-258.

de Brentani, U. (1991) 'Success factors in developing new business services', European Journal of Marketing, Vol. 25, No. 2, pp.33-59.

de Brentani, U. (1993) 'The new product process in financial services: strategy for success', International Journal of Bank Marketing, Vol. 1, No. 3, pp.15-22.

de Brentani, U. (2001) 'Innovative versus incremental new business services: different keys for achieving success', Journal of Product Innovation Management, Vol. 18, No. 3, pp.169-187.

de Brentani, U. and Cooper, R. (1992) 'Developing successful new financial services for businesses', Industrial Marketing Management, Vol. 21, No. 3, pp.231-241.

de Jong, J.P.J. and Vermeulen, P.A.M. (2003) 'Organizing successful new service development: a literature review', Management Decision, Vol. 41, No. 9, pp.844-858.

De Koning, H., Does, R.J.M.M. and Bisgaard, S. (2008) 'Lean Six Sigma in financial services', International Journal of Six Sigma and Competitive Advantage, Vol. 4, No. 1, pp.1-17.

Den Haan, W.J. and Sterk, V. (2010) 'The myth of financial innovation and the great moderation', The Economic Journal, June, Vol. 121, No. 553, pp.707-739.

DeYoung, R., Lang, W.W. and Nolle, D.L. (2007) 'How the internet affects output and performance at community banks', Journal of Banking \& Finance, Vol. 31, No. 4, pp.1033-1060. 
Djellal, F. and Gallouj, F. (2001) 'Patterns of innovation organisation in service firms: postal survey results and theoretical models', Science and Public Policy, Vol. 28, No. 1, pp.57-67.

Dow, J.P. Jr. (2007) 'The adoption of web banking at credit unions', The Quarterly Review of Economics and Finance, Vol. 47, No. 3, pp.435-448.

Drew, S.A.W. (1995) 'Accelerating innovation in financial services', Long Range Planning, Vol. 28, No. 4, pp.1-10.

Easingwood, C.J. (1986) 'New product development for service companies', Journal of Product Innovation Management, Vol. 3, No. 4, pp.264-275.

Edgett, S. and Jones, S. (1991) 'New product development in the financial service industry: a case study', Journal of Marketing Management, Vol. 7, No. 3, pp.271-284.

Edgett, S. and Parkinson, S. (1994) 'The development of new financial services: identifying determinants of success and failure', International Journal of Service Industry Management, Vol. 5, No. 4, pp.24-38.

Flier, B., van den Bosch, F.A.J., Volderba, H.W., Carnevale, C.A., Tomkin, N., Melin, L., Quélin, B.V. and Kriger, M.P. (2001) 'The changing landscape of the European financial services sector', Long Range Planning, Vol. 34, No. 2, pp.179-207.

Frame, W.S. and White, L.J. (2004) 'Empirical studies of financial innovation: lots of talk, little action?', Journal of Economic Literature, Vol. 42, No. 1, pp.116-144.

Frenz, M., Girardone, C. and Ietto-Gillies, G. (2005) 'Multinationality matters in innovation: the case of the UK financial services', Industry and Innovation, Vol. 12, No. 1, pp.65-92.

Froehle, C.M., Roth, A.V., Chase, R.B. and Voss, C.A. (2000) 'Antecedents of new service development effectiveness: an exploratory examination of strategic operations choices', Journal of Service Research, Vol. 3, No. 1, pp.3-17.

Furst, K., Lang, W.W. and Nolle, D.E. (2002) 'Internet banking', Journal of Financial Services Research, Vol. 22, Nos. 1/2, pp.95-117.

Gadrey, J., Gallouj, F. and Weinstein, O. (1995) 'New modes of innovation: how services benefit industry', International Journal of Service Industry Management, Vol. 6, No. 3, pp.4-16.

Goddard, J., Molyneux, P., Wilson, J.O.S. and Tavakoli, M. (2007) 'European banking: an overview', Journal of Banking \& Finance, Vol. 31, No. 7, pp.1911-1935.

Gopalakrishnan, S. and Damanpour, F. (2000) 'The impact of organizational context on innovation adoption in commercial banks', IEEE Transactions on Engineering Management, Vol. 47, No. 1, pp.1-13.

Haskel, J. and Pesole, A. (2011) 'Productivity and innovation in UK financial services: an intangibles asset approach', Discussion paper 2011/02, May 2011.

Heffernan, S.A., Fu, X. and Fu, M. (2008) 'Financial innovation in the UK', available at http://www.ssrn.com/abstract=1266125 or http://dx.doi.org/10.2139/ssrn.1266125 (accessed on 17 July 2012).

Hernando, I. and Nieto, M.J. (2007) 'Is the internet delivery channel changing banks' performance? The case of Spanish banks', Journal of Banking and Finance, Vol. 31, No. 4, pp.1083-1099.

Howcroft, B. and Ataullah, A. (2006) 'Total factor productivity change: an examination of the commercial banking industry in India and Pakistan', The Service Industries Journal, Vol. 26, No. 2, pp.189-202.

Hunt, R.M., Simojoki, S. and Takalo, T. (2009) 'Intellectual property rights and standards setting in financial services: the case of the single European payments area', in Anderloni, L., Llewellyn, D.T. and Schmidt, R.H. (Eds.): Financial Innovation in Retail and Corporate Banking, pp.170-198, Edward Elgar, Cheltenham.

Johne, A. and Harbone, P. (2003) 'One leader is not enough for major new service development: results of a consumer banking study', Service Industries Journal, Vol. 23, No. 3, pp.22-39.

Johne, F.A. and Davies, R. (2000) 'Innovation in medium-sized insurance companies: how marketing adds value', International Journal of Bank Marketing, Vol. 18, No. 1, pp.6-14. 
Johne, F.A. and Harborne, P. (1985) 'How large commercial banks manage product innovation', International Journal of Bank Marketing, Vol. 3, No. 1, pp.54-70.

Johne, F.A. and Storey, C. (1998) 'New service development: a review of the literature and annotated bibliography', European Journal of Marketing, Vol. 32, Nos. 3/4, pp.184-251.

Kane, E.J. (1977) 'Good intentions and unintended evil: the case against selective credit allocation', Journal of Money, Credit, and Banking, Vol. 9, No. 1, pp.55-69.

Kelly, D. and Storey, C. (2000) 'New service development: initiation strategies', International Journal of Service Industry Management, Vol. 11, No. 1, pp.45-63.

Kumar, P. and Turnbull, S.M. (2006) 'Patenting and licensing of financial innovations', Working paper, July, CT Bauer College of Business, University of Houston.

Kumar, S., Wolfe, A.D. and Wolfe, K. (2008) 'Using Six Sigma DMAIC to improve credit initiation process in a financial services operation', International Journal of Productivity and Performance Management, Vol. 56, No. 8, pp.659-676.

Lerner, J. (2006) 'The new new financial thing: the origins of financial innovations', Journal of Financial Economics, Vol. 79, No. 2, pp.223-255.

Lerner, J. (2010) 'The litigation of financial innovations', Journal of Law and Economics, Vol. 53, No. 4, pp.807-831.

Lerner, J. and Tufano P. (2011) 'The consequences of financial innovation: a counterfactual research agenda', Annual Review of Financial Economics, Vol. 3, pp.41-85.

Lievens, A. and Moenaert, R. (2000) 'Project team communication in financial service innovation', Journal of Management Studies, Vol. 37, No. 5, pp.733-766.

Lievens, A. and Moenaert, R. (2001) 'Communication flows during financial service innovation', International Journal of Bank Marketing, Vol. 19, No. 2, pp.68-88.

Lievens, A., Moenaert, R.K. and S'Jegers, R. (1999) 'Linking communication to innovation success in the financial services industry: a case study analysis', International Journal of Services Industries Management, Vol. 10, No. 1, pp.23-48.

Lin, H-F. (2011) 'An empirical investigation of mobile banking adoption: the effect of innovation attributes and knowledge-based trust', International Journal of Information Management, Vol. 31, No. 3, pp.252-260.

Lin, J. (2008) 'The unrealized potential of Six Sigma in finance', Proceedings of ASBBS, Vol. 15, No. 1, pp.472-478.

Llewellyn, D.T. (1992) 'Financial innovation: a basic analysis', in Cavanna, H. (Ed.): Financial Innovation, pp.17-33, Routledge, London.

Lopez, L.E. and Roberts, E.B. (2002) 'First-mover advantages in regimes of weak appropriability: the case of financial services innovations', Journal of Business Research, Vol. 55, No. 12, pp.997-1005.

Manlagñit, M.C.V. (2011) 'The economic effects of foreign bank presence: evidence from the Philippines', Journal of International Money and Finance, Vol. 30, No. 6, pp.1180-1194.

Marcus, A.A. (1981) 'Policy uncertainty and technological innovation', Academy of Management Review, Vol. 6, No. 3, pp.443-448.

Maull, R. and Childe, S. (1994) 'Business process reengineering: an example from the banking sector', International Journal of Service Industry Management, Vol. 5, No. 3, pp.26-34.

Menor, L.J. and Roth, A.V. (2008) 'New service development competence and performance: an empirical investigation in retail banking', Production and Operations Management, Vol. 17, No. 3, pp.267-284.

Merton, R. (1995) 'A functional perspective on financial intermediation', Financial Management, Vol. 24, No. 2, pp.23-41.

Merton, R. and Bodie, Z. (1995) The Global Financial System, a Functional Perspective." Chapter One: A Conceptual Framework for Analyzing the Financial Environment, Harvard Business School Press, Boston. 
Merton, R.C. (1992) 'Financial innovation and economic performance', Journal of Applied Corporate Finance, Winter, Vol. 4, No. 4, pp.12-22.

Miller, M.H. (1986) 'Financial innovation: the last twenty years and the next', Journal of Finance and Quantitative Analysis, Vol. 21, No. 4, pp.459-471.

Milne, A. (2006) 'What is in it for us? Network effects and bank payment innovation', Journal of Banking and Finance, Vol. 30, No. 6, pp.1613-1630.

Molyneux, P. and Shamroukh, N. (1996) 'Diffusion of financial innovations: the case of junk bonds and note issuance facilities', Journal of Money, Credit \& Banking, Vol. 28, No. 3, pp.502-523.

Molyneux, P. and Shamroukh, N. (1999) Financial Innovation, John Wiley, Chichester.

Napoli, R. (2008) 'Innovation in the financial sector: persistence and Schumpeterian hypotheses. Econometric evidence in Germany', Journal of Service Science and Management, Vol. 1, No. 3, pp.215-226.

OECD (2005) Oslo Manual: Guidelines for Collecting and Interpreting Innovation Data, 3rd ed., OECD, Paris.

Oldenboom, N. and Abratt, R. (2000) 'Success and failure factors in developing new banking and insurance services in South Africa’, International Journal of Banking Marketing, Vol. 18, No. 5, pp.233-245.

Oliveira, P. and Von Hippel, E. (2011) 'Users as service innovators: the case of banking services', Research Policy, Vol. 40, No. 6, pp.806-818.

Papastathopoulou, P., Gounaris, S. and Avlonitis, G. (2006) 'Successful new to the market versus 'me-too' retail financial services: the influential role of marketing, sales, E.D.P./systems and operations', International Journal of Bank Marketing, Vol. 24, No. 1, pp.53-70.

Pennings, J.M. and Harianto, F. (1992) 'The diffusion of technological innovation in the commercial banking industry', Strategic Management Journal, Vol. 13, No. 1, pp.29-46.

Phillips, L.W. (1981) 'Assessing measurement error in key informant reports: a methodological note on organizational analysis in marketing', Journal of Marketing Research, Vol. 18, No. 4, pp.395-415.

Reidenbach, R.E. and Moak, D.L. (1986) 'Exploring retail bank performance and new product development: a profile of industry practices', Journal of Product Innovation Management, Vol. 3, No. 3, pp.187-194.

Roberts, P.W. and Amit, R. (2003) 'The dynamics of innovative activity and competitive advantage: the case of Australian retail banking, 1981 to 1995', Organization Science, Vol. 14, No. 2, pp.107-122.

Rossignoli, B. and Arnaboldi, F. (2009) 'Financial innovation: theoretical issues and empirical evidence in Italy and in the UK', International Review of Economics, Vol. 56, No. 3, pp.275-301.

Saunders, A. and Walter, I. (1994) Universal Banking in the US: What We Could Gain? What We Could Lose?, Oxford University Press, New York.

Scheuing, E. and Johnson, E. (1989) 'New product development and management in financial institutions', International Journal of Bank Marketing, Vol. 7, No. 2, pp.17-21.

Shin, N. and Jemella, D. (2002) 'Business process reengineering and performance improvement: the case of Chase Manhattan Bank', Business Process Management Journal, Vol. 8, No. 4, pp.351-363.

Silber, W.L. (1975) Financial Innovation, Heath, Lexington, MA.

Silber, W.L. (1983) 'The process of financial innovation', American Economic Review Papers, Vol. 73, No. 2, pp.89-95.

Storey, C. and Easingwood, C. (1993) 'The impact of the new product development project on the success of financial services', The Service Industries Journal, Vol. 13, No. 3, pp.40-54. 
Storey, C. and Easingwood, C.J. (1996) 'Determinants of new product performance: a study in the financial services sectors', International Journal of Service Industry Management, Vol. 7, No. 1, pp.32-55.

Sundbo, J. and Gallouj, F. (2000) 'Innovation as a loosely coupled system in services', in Metcalfe, J.S. and Miles, I. (Eds.): Innovation Systems in the Service Economy, pp.43-68, Kluwer Academic, Boston.

Sveiby, K.E. (2012) 'Innovation and the global financial crisis - systemic consequences of incompetence', International Journal of Entrepreneurship and Innovation Management, in press.

Tether, B.S. (2005) 'Do services innovate (differently)? Insights from the European innobarometer survey', Industry and Innovation, Vol. 12, No. 2, pp.153-184.

Tether, B.S., Miles, I., Blind, K., Hipp, C., de Liso, N. and Cainelli, G. (2001) 'Innovation in services - an analysis of CIS-2 data on innovation in the service sector', A Report for the European Commission (under CIS Contract 98/184).

Thomke, S. (2003) 'R\&D comes to services: Bank of America's pathbreaking experiments', Harvard Business Review, Vol. 81, No. 4, pp.70-79.

Thwaites, D. (1992) 'Organizational influences on the new product development process in financial services', Journal of Product Innovation Management, Vol. 9, No. 4, pp.303-313.

Thwaites, D. and Edgett, S. (1991) 'Aspects of innovation in a turbulent market environment: empirical evidence from UK building societies', The Service Industries Journal, Vol. 11, No. 3, pp.346-361.

Toivonen, M. and Tuominen, T. (2009) 'Emergence of innovations in services', Service Industries Journal, Vol. 29, No. 7, pp.887-902.

Tufano, P. (1989) 'Financial innovation and first-mover advantages', Journal of Financial Economics, Vol. 25, No. 2, pp.213-240.

Tufano, P. (2003) 'Financial innovation', in Constantinides, G.M., Harris, M. and Stulz, R. (Eds.): Handbook of the Economics of Finance: Corporate Finance, 1685pp, Vol. 1A, pp.307-336, Elsevier, New York.

Uprety, I. (2009) 'Six Sigma in banking services: a case study based approach', International Journal of Six Sigma and Competitive Advantage, Vol. 5, No. 3, pp.251-271.

Van Ark, B., Hao, J.X., Corrado, C. and Hulten, C. (2009) 'Measuring intangible capital and its contribution to economic growth in Europe', in Strauss, H. (Ed.): R\&D and the Financing of Innovation in Europe, Vol. 14, No. 1, pp.62-93, EIB Papers, Luxembourg.

Van Horne, J.C. (1985) 'Of financial innovations and excesses', The Journal of Finance, Vol. 40, No. 3, pp.621-631.

Vence, X. and Trigo, A. (2009) 'Diversity of innovation patterns in services', Service Industries Journal, Vol. 29, No. 12, pp.1635-1657.

Venkatraman, N. and Ramanujam, V. (1986) 'Measurement of business performance in strategy research: a comparison of approaches', The Academy of Management Review, Vol. 11, No. 4, pp.801-814.

Vermeulen, P. (2004) 'Managing product innovation in financial services firms', European Management Journal, Vol. 22, No. 1, pp.43-50.

Vermeulen, P. and Dankbaar, B. (2002) 'The organisation of product innovation in the financial sector', Service Industries Journal, Vol. 22, No. 3, pp.77-98.

Vermeulen, P.A.M., Van Den Bosch, F.A.J. and Volberda, H.W. (2007) 'Complex incremental product innovation in established service firms: a micro institutional perspective', Organization Studies, Vol. 28, No. 10, pp.1523-1546.

Vives, X. (2001) 'Competition in the changing world of banking', Oxford Review of Economic Policy, Vol. 17, No. 4, pp.535-547. 
Yang, S-C., Tu, C. and Yang, S. (2009) 'Exploring the solution - the contextual effect on consumer dissatisfaction and innovativeness in financial service companies', The Service Industries Journal, Vol. 29, No. 4, pp.557-568.

Yildirim, H.S. and Philippatos, G.C. (2007) 'Restructuring consolidation and competition in Latin American banking markets', Journal of Banking and Finance, Vol. 31, No. 3, pp.629-639.

\section{Newspaper articles and web documents}

The Economist (2012a) Special report on Financial Innovation, 25 February.

The Economist (2012b) Special report on International Banking, 19 May.

The New York Times (2009) 'Money for nothing', available at http://www.nytimes.com/2009/ 04/27/opinion/27krugman.html (accessed on 17 July 2012). 